\title{
Ialp News
}

Consultative status with WHO, UNESCO and UNICEF

Avis aux membres índividuels de IALP

Les membres individuels sont informés que l'élection du President et des membres du nouveau Board aura lieu lors du prochain Congrès (Paris) et qu'ils peuvent faire des suggestions et nominations pour cette election, en écrivant au Secretaire General, avant le 30 juillet 1968. 392

IALP News

To the members and affiliated Associations of IALP

We have received a communication from Unesco asking us to draw up a list of institutions offering possibilities for studies and investigations on a high level of special education for children and young people, disabled in hearing and speaking.

The General Secretary of IALP asks you to send him this information as soon as possible. Avis für die índivíduellen Mitglieder der IALP

Die individuellen Mitglieder werden informiert, dass die Wahl des Präsidenten und der Mitglieder des neuen Vorstands am nächsten Kongress in Paris stattfinden wird. Vorschläge für diese Wahl sind an das General-Sekretariat vor dem 30. Juli 1968 zu übersenden.

Congresses

American Cleft Palate Association

The American Cleft Palate Association announces its plans to sponsor an International Congress on the subject of Cleft Palate from April 14 to April 17, 1969, at the Shamrock-Hilton Hotel in Houston, Texas. Further information relative to this Congress may be obtained by writing to Betty Jane McWílliams, Ph.D., Cleft Palate Research Center, The University of Pittsburgh, 320 Salk Hall, Pittsburgh, Pennsylvania 15213. USA.

Speech Production in Man and Machines

From November 8-11,1967 a symposium was held in the Communication Sciences Laboratory, Department of Speech, University of Florida, Gainesville, on speech production in man and machines, featuring Gunnar Fant (Stockholm), Hollíen, Líebjencrants, Paige, Tiffany, Tolhurst, Truby, Dew, Markel and Scholes.

IIIe Congrès argentín de Phoniatrie et Audíologíe

Du 7 au 10 décembre 1967 a eu lieu le IIIe Congrès argentin de Phoniatrie et Audiologie à Alta Gracia, Cordoba. Les rapports officiels ont été dirigés par les Prof. J. M. Tato, 0. Suáres, J. B. de Quírós, R. Segre et E. Romero.

Cours

Cours d, audiomêtríe Cliníque

Du jeudi 18 avril au mercredi 24 avril 1968 aura lieu au Centre de Phono-Audiologie de la Faculté de Médecine de Bordeaux, un cours d'Audiométrie Clinique dirigé par le Prof. M. Portmann, avec la collaboration des Drs F. Lhermítte, A. Mor-gon, J. C. Lafon et MM. M. Gautíe et J. Fournier. 